\title{
Regional Differences in the Capital Structure of Hungarian SMEs
}

\author{
Veronika GÁL
}

Department of Finance and Accounting, Faculty of Economic Sciences, Kaposvár University, Kaposvár, Hungary

E-mail: gal.veronika@ke.hu

\section{Katalin GÁSPÁR}

Department of Economics, Faculty of Economics and Human Sciences, Sapientia-Hungarian University of Transylvania, Miercurea Ciuc E-mail: gaspark@uni-corvinus.hu

\author{
Anett PARÁDI-DOLGOS \\ Department of Finance and Accounting, Faculty of Economic Sciences, Kaposvár \\ University, Kaposvár, Hungary \\ E-mail: dolgos.anett@ke.hu
}

\begin{abstract}
Small and medium-sized enterprises play an important role in employment and also significantly contribute to GDP production. Therefore, an important function of economic policy in all countries is to create an economic milieu that supports the SMEs' operation. By analysing several economic indices of SMEs in Hungary, we could identify that there are significant differences between the regions. About 40 percent of the enterprises are located in the Central Hungary Region. By examining specific indices of these firms, we can tell that enterprises operating in this region provide higher performance in the point of Return and Gross Value Added. The aim of this study is to assert that regional differences can be found not only in the performance of firms, but also in their capital structure. As a proof of this, we analysed the regional breakdown of capital structure based on a database which contains corporate income tax declaration data of Hungarian joint small and medium-sized enterprises (168,070 firms), and then we separated different financing characteristics by using cluster analysis. Finally, we discovered those endogenous and exogenous factors that could generate the disclosed regional differences and which interact with the performance of enterprises.
\end{abstract}

Keywords: financing, capital structure indices, cluster, WEKA, determining factors.

JEL Classification: G32 


\section{Introduction}

The role of small and medium-sized enterprises (SME) in the economy justifies that we must give high priority to this sector. But the phrase SME denotes an extremely diversified group of firms. This heterogeneity can be observed not only in their total number of staff, annual turnover or annual balance sheet total - on which the legal demarcation is based - but also in their micro- and macro-milieu and in their activities. Based on this, firms are also faced with different financing problems and opportunities in the course of their operation, and as a result of this their capital structures are dissimilar.

Capital structure is the distribution of the cash flow of a company's investments between the holders of related assets and the long-term financial claims. When the financial officer decides about the financing of a project, he actually determines the combination of the holders of claims. Most frequently, the literature uses the leverage and gearing indices to characterize capital structure. The leverage is measured by the ratio of total (long-term and short-term) liabilities to total assets, while gearing is measured by the ratio of total liabilities to equity (Brealey \& Myers, 2005).

The theoretical and empirical literature of determining factors of capital structure is rich and diversified. The classical capital structure doctrines are originated from the authors Modigliani and Miller; their research defines the literature of capital structure to this day. Based on their model with robust suppositions (e.g. the capital market is perfect, and there are no taxes and transaction costs), they were led to the conclusion that the market value of the firm is independent from its capital structure (Modigliani \& Miller, 1958). The aim of the majority of capital structure theories inspired by their result was to lift their assumptions. The step-by-step challenging of assumptions brings the theories nearer and nearer to the reality.

Interpreter theories of companies' capital structure have a history of more than fifty years. The earliest and, since then, determining doctrines and empirical results were born in the 50s in the United States. Statistics, which make analyses of Hungarian companies possible, have been compiled in Hungary since the regime change and the birth of the stock exchange. The earliest studies were based on data of large and mainly stock exchange listed companies. Later, analyses concentrated on a particular sector (e.g. manufacturing firms), and began to take notice of companies of all sizes. Papers concentrating on SMEs' capital structure appeared after 2000.

In this study, we focus on Hungarian SMEs' capital structure. In sections 2 and 3, we characterize the SMEs of Hungary. Section 4 describes the material and the methods. In Section 5, we investigate whether the regional differences we have found in the firms' performance also characterize the capital structure of the enterprises. In Section 6, we explore which endogenous (company size, sectoral breakdown, 
asset's coverage capability, market position) and exogenous (characteristic of input and output markets, macroeconomic characteristics) determinants may have significant effect on the financial decisions of SMEs and which could generate the disclosed regional differences. Finally, Section 7 concludes.

\section{SMEs' Definition and Economic Importance}

The definition of small and medium-sized enterprises (SMEs) regulates the Hungarian Act XXXIV of 2004 on Small and Medium-Sized Enterprises and the Promotion of Their Development. From the first of January 2005, according to 2003/361/EC Commission Recommendation concerning the definition of micro-, small and medium-sized enterprises, the conceptual demarcations of the law are the followings:

“3. § (1) An enterprise is qualified as SME if its total staff number is fewer than 250 persons and its annual turnover is up to 50 million euros in Hungarian forint, or its annual balance sheet total is up to 43 million Euros in Hungarian Forint.

(2) An enterprise is qualified as a small-sized enterprise if its total staff number is fewer than 50 persons and its annual turnover or its annual balance sheet total is up to 10 million euros in Hungarian forint.

(3) An enterprise is qualified as micro-sized enterprise if its total staff number is fewer than 10 persons and its annual turnover or its annual balance sheet total is up to 2 million euros in Hungarian forint.

(4) Those enterprises do not qualify as SMEs that have a direct or indirect property share of the state or the local government which exceeds, separately or jointly, 25\%."

In Hungary, the vast majority of the enterprises belong to the category of SMEs. In 2009, 95 percent of the enterprises belonged to the category of micro-sized enterprises, based on the total staff number distribution. Beyond their numerical superiority, their size basically influences their revenue-generating capability, their contribution to the GDP, to employment and to development.

In 2009, 56 percent of Gross Value Added was produced by SMEs, while they provided jobs to three-quarters of the employed. They give more than 50 percent of the Hungarian firms' net annual turnover and investments. Their role in employment is considerable as they do typically more labour-intensive activities (Kotulics, 2010).

Hungarian SMEs' revenue-generating capability is one-tenth of the EU15's average. Less than 20 percent of the enterprises are bankable (the rate in the EU is $70-85 \%$ ) and just a negligible number of them has got sensible help from enterprise development systems (NFGM, 2009). 


\section{Regional Differences of SMEs}

Table 1. Main indices of SMEs, 2009

\begin{tabular}{lllllll}
\hline Area & $\begin{array}{c}\text { Number of } \\
\text { SMEs }\end{array}$ & $\begin{array}{c}\text { Number of } \\
\text { employees }\end{array}$ & $\begin{array}{c}\text { Gross value } \\
\text { added }\end{array}$ & $\begin{array}{c}\text { Sales } \\
\text { revenue }\end{array}$ & Investment & $\begin{array}{c}\text { Foreign } \\
\text { capital }\end{array}$ \\
\hline Central Hungary & 274258 & 834519 & 3907 & 24802 & 887 & 5678 \\
\hline $\begin{array}{l}\text { Central } \\
\text { Transdanubia }\end{array}$ & 69597 & 195457 & 577 & 2854 & 147 & 502 \\
\hline $\begin{array}{l}\text { Western } \\
\text { Transdanubia }\end{array}$ & 68314 & 193928 & 556 & 2729 & 137 & 292 \\
\hline $\begin{array}{l}\text { Southern } \\
\text { Transdanubia }\end{array}$ & 58604 & 159623 & 389 & 2059 & 197 & 98 \\
\hline $\begin{array}{l}\text { Northern } \\
\text { Hungary }\end{array}$ & 59396 & 163291 & 457 & 2381 & 90 & 245 \\
\hline $\begin{array}{l}\text { Northern Great } \\
\text { Plain }\end{array}$ & 79365 & 231014 & 594 & 3300 & 148 & 164 \\
\hline $\begin{array}{l}\text { Southern Great } \\
\text { Plain }\end{array}$ & 78592 & 233932 & 625 & 3469 & 172 & 159 \\
\hline Hungary total & $\mathbf{6 8 8 1 2 6}$ & $\mathbf{2 0 1 1 7 6 4}$ & $\mathbf{7 1 0 5}$ & $\mathbf{4 1 5 9 4}$ & $\mathbf{1 7 8 9}$ & $\mathbf{7 1 3 7}$ \\
\hline
\end{tabular}

Table 1 contains the Hungarian SMEs' most important economic indices broken down by regions. We can see that the Central Hungary Region excels at all points. It represents more than 50 percent rate in point of gross value added and sales revenue, while in point of foreign capital this rate is about 80 percent.

The differences are even more conspicuous on specific (per unit) data investigation. In point of gross value added and investments per SME, the Central Hungary Region has half as much benefit compared to the other regions. In the case of sales revenue per SME, this difference is more than the double, while in the case of foreign capital it is about sextuple. In point of the average number of employees, there are no significant differences between the regions.

Upon the investigation of the rate of gross value added to sales revenue, as the index of operation's efficiency, we found that this index is also lowest in the Central Hungary Region.

\section{Material and methods}

Századvég Economic Research Ltd. gave free run of the database, which we used for our analyses. This database contains Hungarian joint SMEs balance sheet and income statement data from their corporate income tax declarations from 2007 to 2011. However, in the course of the present analysis, we concentrate only on the data of the year 2010 because adequate background variables (county 
code, region code, TEÁOR classification) were available in that year only. To the division of the activities, the TEÁOR (unified sectoral classification system of economic activities) '08 classification's main groups were available.

Firms of the capital city, Budapest, act otherwise in many ways (e.g. type of activities) compared to other enterprises from the region's other settlements. That is why it is justifiable to run Budapest as a separate territorial unit. With the help of the county code, Budapest became isolable from the other settlements of the Central Hungarian Region; so, apropos of territorial differences, next to the seven Hungarian regions, we could represent the capital city's data separately.

The database also contains SME classification given by firms, but that has been in many cases deficient or wrong. Therefore, as the start of the analysis after the replacement and correction of this, we made another classification to the database based on the number of employees. We eliminated enterprises with the total staff number zero or unknown, and those with more than 249 employees. The created categories were: in the case of 1-9 employees "micro-," 10-49 employees "small" and 50-249 employees "medium" enterprises.

To give a presentation of the capital structure, at first, we investigated SMEs' aggregated capital structure. But the interpretation of the results was made difficult by the fact that many firms, mainly micro-enterprises, were characterized by zero or negative equity. Therefore, these firms, although not eliminated, were separated and further on run as a separate group.

To characterize firms with positive equity, we chose the further three capital structure indicators:

1) Equity ratio: we calculated as the ratio of equity and total sources.

2) Long-term debt ratio: we calculated as ratio of long-term debts and durable sources.

3) Accountants payable ratio: we calculated as ratio of accounts payable and total liabilities.

Based on the three indices, we separated different financing characteristics by using cluster analysis. Out of the potential analysing methods, we chose K-means clustering and - based on performed examinations - it was justified to use 6 clusters. We made the analysis with WEKA data mining software. WEKA (Waikato Environment for Knowledge Analysis) is a free, unlimited access package developed by Waikato University in New Zealand. Its open-source code and modular construction enables further developments; therefore, new features are added continuously (Abonyi, 2006). 


\section{Capital Structure in the Light of the Regions}

Figure 1 shows joint SMEs from the database (in total, 168,070 firms) aggregated capital structure by territorial location. We can see that the average ratio of the equity is $37 \%$ in Hungary. We found lower ratio in the case of Budapest, as in the case of other regions it is higher. The ratio of long-term debts exceeds the countywide average only in the case of Central Hungary Region; in other regions, its value is significantly behind.

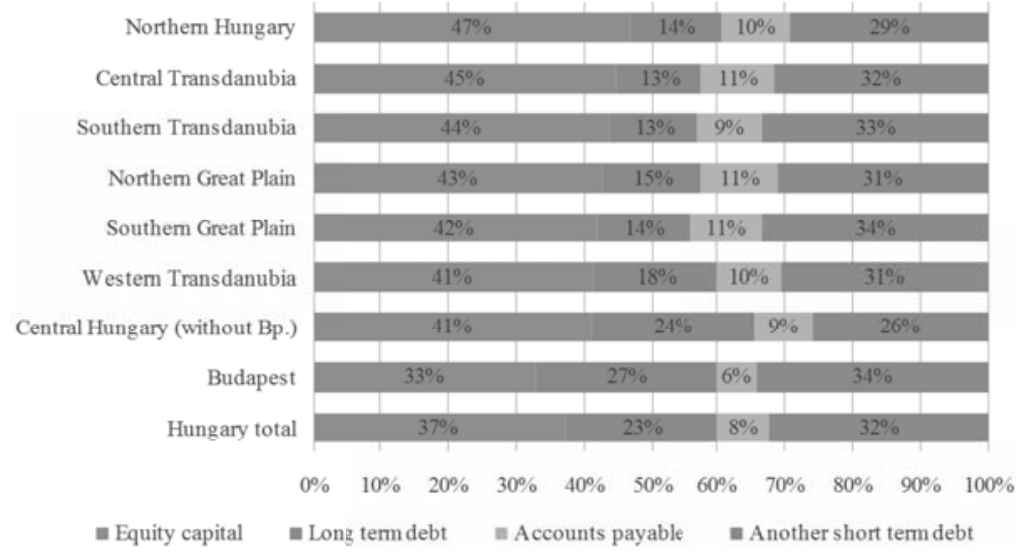

Figure 1. Regional differences in SMEs' aggregate capital structure, 2010

Comparing aggregated capital structure's regional data and EU's Development Ranking (Eurostat 2011), we found that in more developed areas (Central Hungary, Western Transdanubia) a lower ratio of equity and a higher ratio of durable liability is typical, more so than in less developed regions (Northern Hungary, Southern Transdanubia). The result is distorted by the firms' data with non-positive equity, whose ratio in the Central Hungary Region is higher than 20 percent.

\section{Clusters of Capital Structure}

Table 2. Result of cluster analysis

\begin{tabular}{lccccccc}
\hline Cluster's name & Cluster1 & Cluster2 & Cluster3 & Cluster4 & Cluster5 & Cluster6 & Total \\
\hline Number of firms & 38,358 & 32,092 & 16,434 & 19,691 & 14,219 & 15,294 & 136,088 \\
\hline Rate of firms & $28.19 \%$ & $23.58 \%$ & $12.08 \%$ & $14.47 \%$ & $10.45 \%$ & $11.24 \%$ & $100.00 \%$ \\
\hline
\end{tabular}

The result of the clustering is shown in Table 2. More than half of the 136,088 enterprises with positive equity came to the first and second cluster, while the size of the other groups is about the same; they contain units between 14,000 and 20,000 pieces. 
Figure 2 illustrates the capital structure indicators of the clusters with the help of box plots. In the diagram, the boxes are delimited by lower and higher quartiles, while the total range of the data is observable through the line from the boxes. We can show that, as a result of clustering, we can identify well-separated capital structure characteristics referring to Hungarian SMEs.

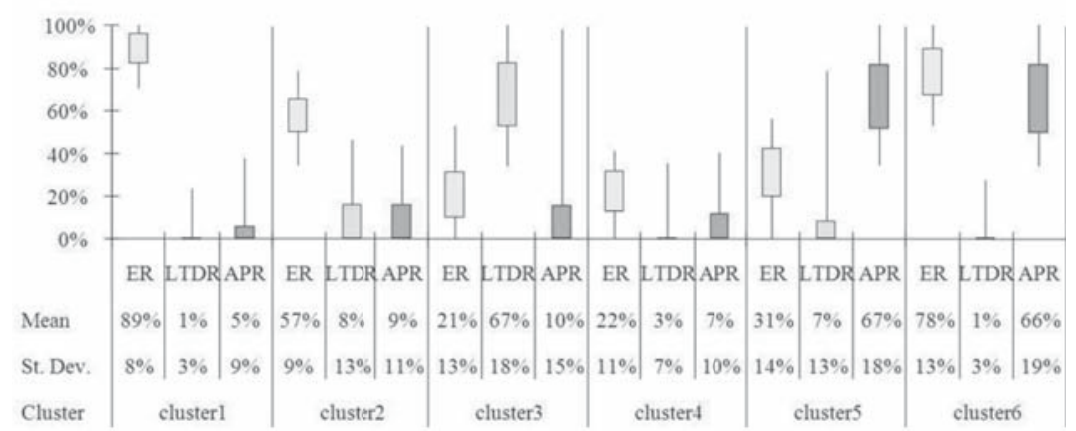

Figure 2. Equity ratio (ER), long-term debt ratio (LTDR) and accounts payable ratio (APR) by clusters, 2010

In cluster1, the dominance of equity is typical; hence this group's name is "high equity". In cluster2, next to the medium ratio of equity, the roles of long-term debts and accounts payable also turn up. This group's name is "medium equity". In cluster3, long-term debts dominate; hence, this group's name is "high long-term debt". In cluster4, the value of all indices is low; hence, its name is "other source". In cluster5, next to equity, the high ratio of trade credit is typical; hence, its name is "high trade credit". In the case of cluster6, the ratio of equity and trade credit is also high; hence, this group's name is "high equity and trade credit".

\section{Financing Characteristics in the Regions}

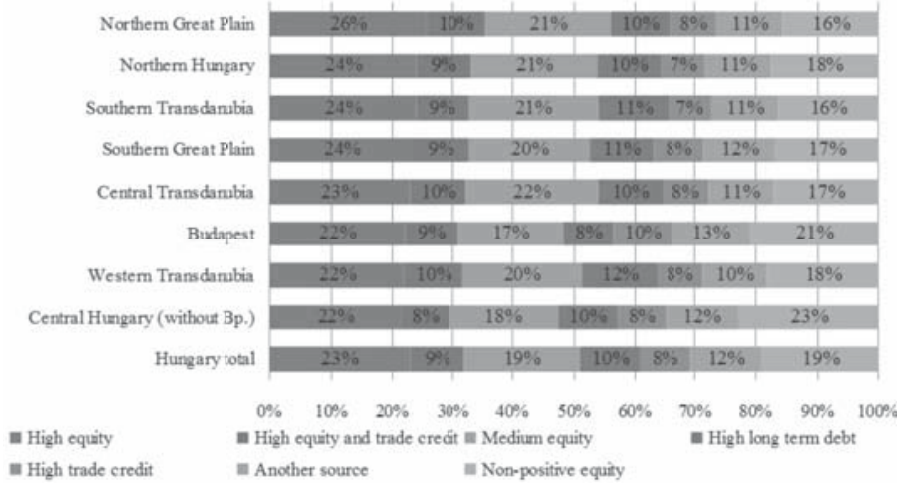

Figure 3. Capital structure clusters by regions, 2010 
Figure 3 shows that results may be similar to the rank of development by regions. While about 60 percent of the firms in the Northern Great Plain Region finance their operation mainly with equity, this ratio is lower than 50 percent in the Central Hungary Region and in Budapest. Firms operating with high trade credit concentrated in the capital city and its surroundings, and non-positive equity is typical here. Enterprises with high stock of long-term debt are typical primarily in the Western Transdanubia Region.

\section{How Can We Explain the Regional Differences?}

Henceforth, we present and analyse some factors that influence the capital structures of the firms and through them we interpret the regional differences.

Krénusz (2007) divided the determining factors of capital structure (determinants) into two large groups. She named macro-factors those regionalor country-specific characteristics on which companies have no effect. These factors outwardly influence (exogenously) the financing decisions of firms. The micro-factors (endogenous factors) are the peculiarity of the companies which directly affect capital structure policy.

The literature of micro-factors discusses several determinants, from which we investigated firm size, character of activities, tangibility (coverability) and market position, as the importance of trade credit. With the help of them, we interpret the regional differences of financing characteristics in Hungary.

The literature of capital structure discusses the following macro-factors: macroeconomic characteristics, legal system, development of financial intermediation, tax system, corporate governance and characteristics of input and output markets. Some of these macroeconomic characteristics (mainly GDP per capita) and the characteristics of input and output markets may contain relevant factors if we analyse the differences between the regions.

\section{Effect of Company Size on Capital Structure}

Large companies, because of their size and diversified activities, have lower risk in the course of lending; therefore, they get borrowing capital easier. The lower risk means simultaneously cheaper financing sources, which are associated with lower specific transaction costs. The probability of bankruptcy and bankruptcy costs is proportionally much lower for large firms compared to SMEs (Warner, 1977). Therefore, we expect company size to be positively related to leverage.

Empirical studies done with data on small enterprises found the relationship between firm size and total liabilities and long term-debt to be a positive one (e.g. Jensen and Uhl, 2008; Psillaki and Daskalakis, 2009). 
Table 3. Rate of categories by firm size in the regions

\begin{tabular}{|c|c|c|c|c|c|}
\hline Area & Categories & Micro & Small & Medium & Total \\
\hline \multirow{2}{*}{$\begin{array}{l}\text { Central Hungary } \\
\text { (without Bp.) }\end{array}$} & number & 20,519 & 2,391 & 422 & 23,332 \\
\hline & rate & $\mathbf{8 8} \%$ & $10 \%$ & $2 \%$ & $100 \%$ \\
\hline \multirow{2}{*}{ Budapest } & number & 47,930 & 6,451 & 1,141 & 55,522 \\
\hline & rate & $\mathbf{8 6} \%$ & $12 \%$ & $2 \%$ & $100 \%$ \\
\hline \multirow{2}{*}{$\begin{array}{l}\text { Southern } \\
\text { Transdanubia }\end{array}$} & number & 11,100 & 1,576 & 289 & 12,965 \\
\hline & rate & $\mathbf{8 6} \%$ & $12 \%$ & $2 \%$ & $100 \%$ \\
\hline \multirow{2}{*}{$\begin{array}{l}\text { Northern } \\
\text { Hungary }\end{array}$} & number & 10,474 & 1,468 & 298 & 12,240 \\
\hline & rate & $\mathbf{8 6} \%$ & $12 \%$ & $2 \%$ & $100 \%$ \\
\hline \multirow{2}{*}{$\begin{array}{l}\text { Central } \\
\text { Transdanubia }\end{array}$} & number & 12,818 & 1,859 & 327 & 15,004 \\
\hline & rate & $85 \%$ & $12 \%$ & $2 \%$ & $100 \%$ \\
\hline \multirow{2}{*}{$\begin{array}{l}\text { Western } \\
\text { Transdanubia }\end{array}$} & number & 12,280 & 1,818 & 383 & 14,481 \\
\hline & rate & $85 \%$ & $13 \%$ & $3 \%$ & $100 \%$ \\
\hline \multirow{2}{*}{$\begin{array}{l}\text { Northern Great } \\
\text { Plain }\end{array}$} & number & 14,511 & 2,183 & 483 & 17,177 \\
\hline & rate & $84 \%$ & $13 \%$ & $3 \%$ & $100 \%$ \\
\hline \multirow{2}{*}{$\begin{array}{l}\text { Southern Great } \\
\text { Plain }\end{array}$} & number & 14,547 & 2,354 & 448 & 17,349 \\
\hline & rate & $84 \%$ & $14 \%$ & $3 \%$ & $100 \%$ \\
\hline \multirow{2}{*}{ Hungary total } & number & 144,179 & 20,100 & 3,791 & 168,070 \\
\hline & rate & $\mathbf{8 6} \%$ & $12 \%$ & $2 \%$ & $100 \%$ \\
\hline
\end{tabular}

In Table 3, we can see that, although there are no huge differences between regions in the territories, in more developed regions, the ratio of micro-enterprises is higher, while in less developed regions small and medium-size enterprises are overrepresented as compared to Hungary's average.

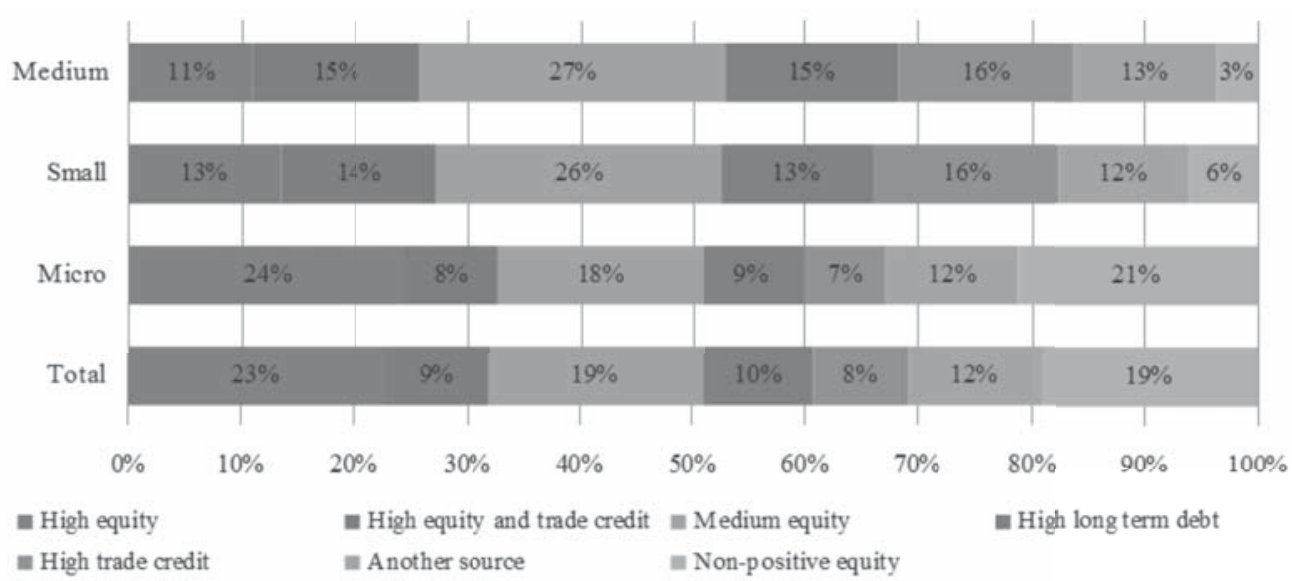

Figure 4. Distribution of capital structure clusters by firm size, 2010 
Figure 4, which visualizes financing characteristics by company size, also shows huge differences. While every third micro-sized enterprise finances themselves quasi with equity alone, this is typical only for every fourth mediumsized enterprise. With an increase in size, long-term debt acquires higher importance. Trade credit already has a doubled importance in the small-sized category compared to the smallest-sized firm category. Non-positive equity is typical mainly in micro-sized enterprises.

Based on the capital structure clusters, it would be expectable that in more developed regions the ratio of enterprises financed mainly by equity to be higher - namely, the opposite of what we have found; therefore, firm size can not justify regional differences.

\section{Effect of Sectoral Breakdown on Capital Structure}

The characteristic of the activity is one of the most important determining factors of capital structure. The capital structures of firms in the same sector are always very similar. And sectors also tend to hold rank of relative leverage over the years. From this conception, we could demarcate firms with low, medium and high leverage (Harris and Raviv, 1991). Enterprises with low leverage are, among others, the cosmetic industry, electronic, food industry, engineering firms and publishing. Enterprises with medium leverage are, among others, pulpwood, construction, petroleum extraction and refining or chemical industry. And high leverage is typical in retail food stores, air transport, electricity and gas supply, telephone services, textile industry or trucking.

Table 4 shows that the four biggest sectors in every region are trade and repairing, professional and scientific activities, manufacturing and constructing. Next to these, other activities play an important role in each region.

Budapest also differs from other regions by activities. Next to the four biggest TEÁOR main groups, there is also a high ratio in the cases of real estate activities, information and communication, and administrative activities. Human health services are concentrated in northern areas, while transportation and storage are mainly in the county's central areas. 
Table 4. Rate of activities in the regions

\begin{tabular}{|c|c|c|c|c|c|c|c|c|c|}
\hline Activities & 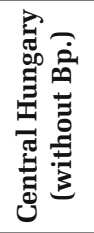 & 总 & 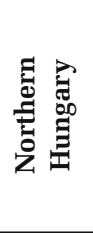 & 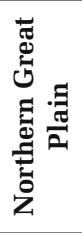 & 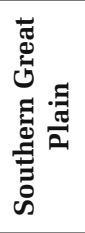 & 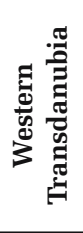 & ن & ڤ & हृँ \\
\hline Trade, repairing & $26 \%$ & $26 \%$ & $27 \%$ & $29 \%$ & $29 \%$ & $27 \%$ & $25 \%$ & $26 \%$ & $27 \%$ \\
\hline $\begin{array}{l}\text { Professional and } \\
\text { scientific activities }\end{array}$ & $11 \%$ & $18 \%$ & $10 \%$ & $10 \%$ & $10 \%$ & $10 \%$ & $10 \%$ & $10 \%$ & $13 \%$ \\
\hline Manufacturing & $13 \%$ & $\mathbf{9} \%$ & $14 \%$ & $12 \%$ & $14 \%$ & $13 \%$ & $14 \%$ & $13 \%$ & $12 \%$ \\
\hline Construction & $13 \%$ & $7 \%$ & $11 \%$ & $10 \%$ & $9 \%$ & $10 \%$ & $12 \%$ & $11 \%$ & $10 \%$ \\
\hline Real estate activities & $5 \%$ & $7 \%$ & $4 \%$ & $4 \%$ & $4 \%$ & $6 \%$ & $5 \%$ & $5 \%$ & $6 \%$ \\
\hline Human health & $4 \%$ & $4 \%$ & $8 \%$ & $7 \%$ & $6 \%$ & $6 \%$ & $6 \%$ & $6 \%$ & $5 \%$ \\
\hline $\begin{array}{l}\text { Accommodation and } \\
\text { food service }\end{array}$ & $3 \%$ & $4 \%$ & $5 \%$ & $4 \%$ & $5 \%$ & $6 \%$ & $5 \%$ & $6 \%$ & $5 \%$ \\
\hline $\begin{array}{l}\text { Information and } \\
\text { communication }\end{array}$ & $4 \%$ & $7 \%$ & $3 \%$ & $3 \%$ & $3 \%$ & $3 \%$ & $3 \%$ & $3 \%$ & $5 \%$ \\
\hline $\begin{array}{l}\text { Administrative } \\
\text { activities }\end{array}$ & $4 \%$ & $5 \%$ & $3 \%$ & $3 \%$ & $3 \%$ & $3 \%$ & $4 \%$ & $3 \%$ & $4 \%$ \\
\hline $\begin{array}{l}\text { Transportation and } \\
\text { storage }\end{array}$ & $5 \%$ & $3 \%$ & $4 \%$ & $4 \%$ & $4 \%$ & $4 \%$ & $5 \%$ & $3 \%$ & $4 \%$ \\
\hline $\begin{array}{l}\text { Agriculture, forestry, } \\
\text { fishing }\end{array}$ & $2 \%$ & 0\% & $4 \%$ & $6 \%$ & $5 \%$ & $4 \%$ & $3 \%$ & $6 \%$ & $3 \%$ \\
\hline Other activities & $8 \%$ & $9 \%$ & $8 \%$ & $8 \%$ & $8 \%$ & $8 \%$ & $7 \%$ & $8 \%$ & $8 \%$ \\
\hline
\end{tabular}

Figure 5 demonstrates the proportion of enterprises in each cluster according to the TEÁOR classification. The ratio of firms financing mainly with equity is low in trade and repairing, transportation and storage or electricity, gas and steam supply. In accommodation and food service, the ratio of equity is also low, but this is the sector where the ratio of enterprises with non-positive equity is the highest, which influences the results. In the sector of agriculture, real estate activities or the information and communication, more than one third of the firms finance themselves mainly with equity. The lowest leverage is typical in professional and scientific activities, arts and entertainment, financial and insurance activities, human health activities and education.

A higher role of debts is noticeable next to firms with low leverage in real estate activities. The role of trade credit is high in construction and trade, repairing, but it is also important in electricity gas and steam supply. It has a lower role in human health activities, accommodation and food services and financial and insurance activities. Our results, due to the dissimilarity of classification, could not parallel the result of Harris and Raviv (1991). But we obtained the same result in the case of the medium leverage of construction and enterprises with high leverage (trade and repairing; electricity and gas supply; transportation and storage). 


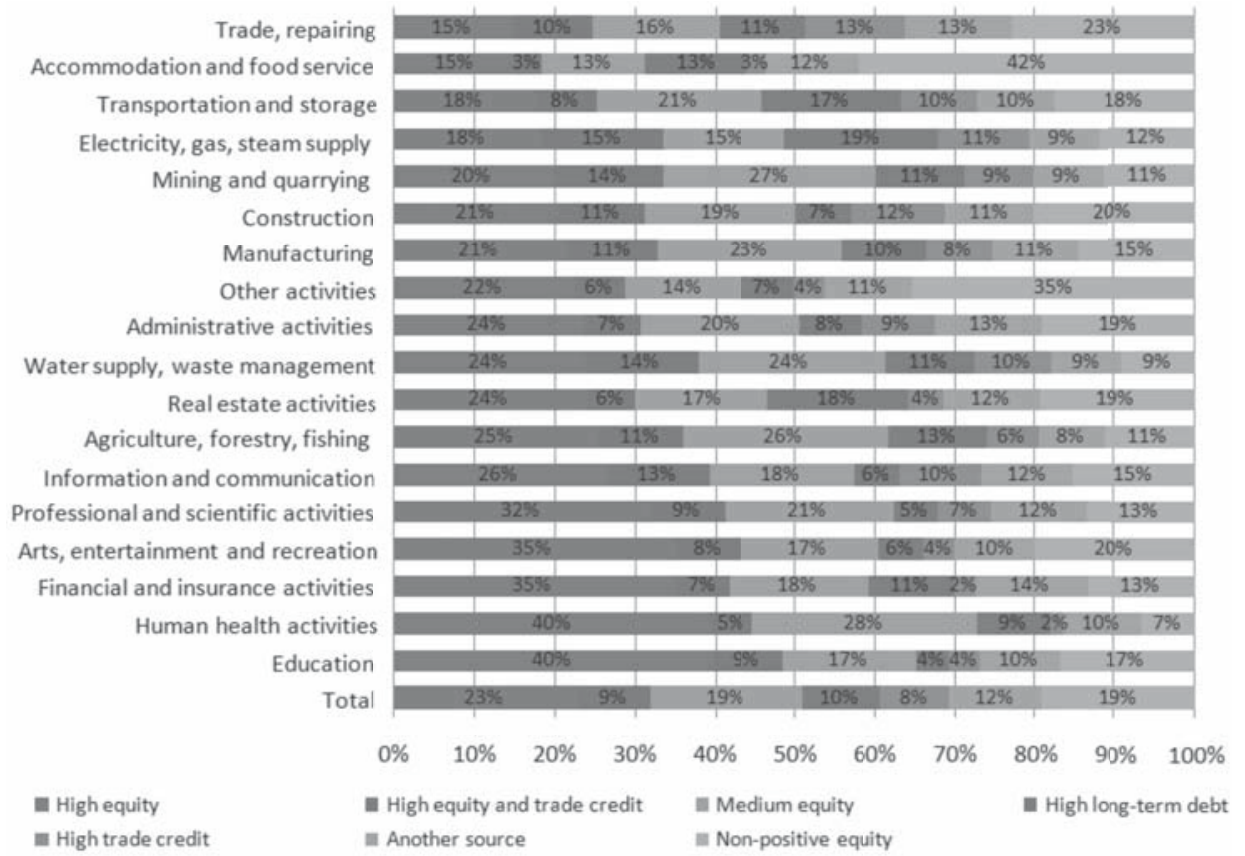

Figure 5. Distribution of capital structure clusters by activities, 2010

After comparing the financing characteristics of the biggest sector, trade and repairing (Figure 6), with the total sample, we can say: the territorial differences are the same in this sector as well as in the whole sample.

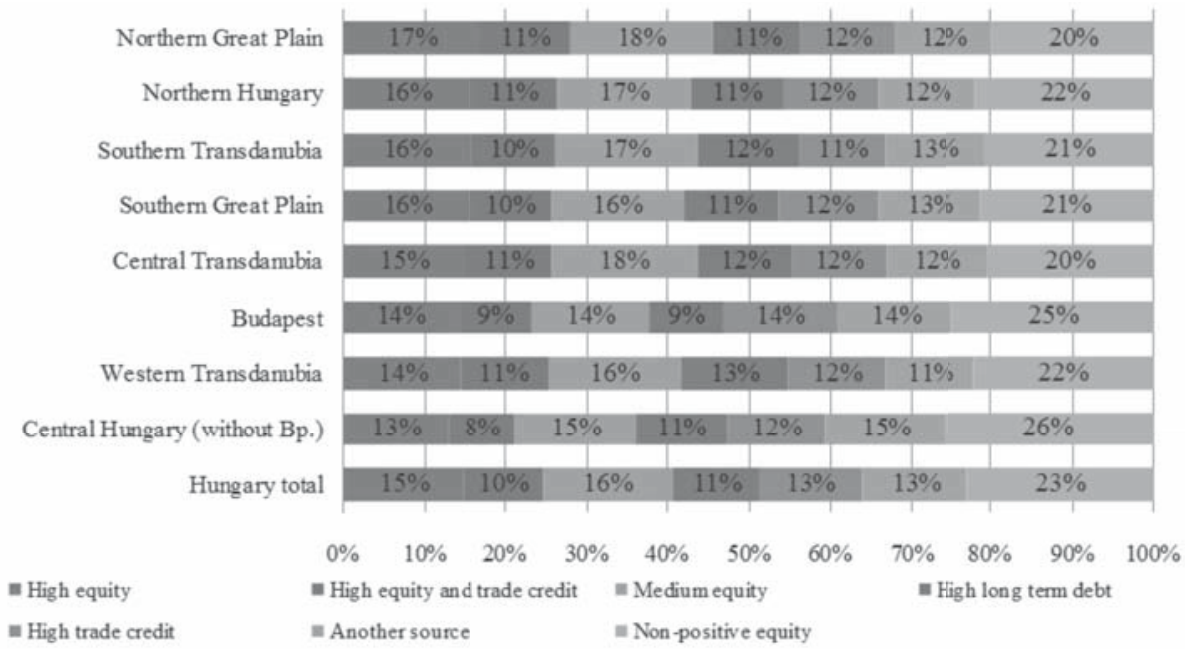

Figure 6. Distribution of capital structure clusters in the trade and repairing sector, 2010 
Due to the territorial differences of activities, we could not interpret capital structure differences between territorial units. Based on our investigations, our conclusion is that regional differences are also observable in the activities; thus, activity is not an adequate determining factor.

\section{Coverage Capability of the Asset}

We can search the coverage capability of the asset with a component of assets, tangibility. The higher the rate of fix assets compared with the total assets, the more creditable the firm, and so the lower the risk to creditors.

In the case of large companies, there is a significantly negative relationship (e.g. Balla \& Mateus, 2004) and in the case of SMEs there is a positive relationship (e.g. Sogorb, 2002; Song 2005) between tangibility and total debt. In the case of long-term liabilities, a positive relationship is documented independently from size. Therefore, higher coverability has a significant relationship rather with long-term than with short-term borrowing sources.

The covering function of asset has a greater role in smaller companies because they finance themselves out of durable sources rather than with long-term loans, as larger ones do with retained earnings and share capital.

The value of collateral coated tools is influenced by their marketability. In the case of a machine, it could reduce its value whether it is just due to delay or to high transportation costs. In the case of real estates, it means that real estates with the same parameters represent a higher coverage value in a city than in a little town. It would be the interpretation of our results why do lower typical firms finance mainly with long-term liabilities in less developed regions.

\section{Market Position}

Market position, by our reading, is a firm's ability regarding how effectively it can turn in their claims or use opportunity of vendor financing. Trade credit can be seen as the price discrimination's instrument, as marketing instrument or the instrument to reduce specific transaction costs as well. In several cases, the advantage of trade credit is higher than the lost benefit (Kihanga, 2010).

SMEs cannot vary significantly from prompts used in the economic sector because smaller prompt causes market loss, just as with longer prompts further customers can be won; however, this causes deterioration of profitability and, soon, problems with liquidity. Based on Figure 5, we found that vendor financing has a higher role in construction and trade.

A high stock of accounts receivable could allude to a wrong market position. A high stock of accounts payable can be interpreted as a mark of good market position and trust between clients, but it could come from wrong payment discipline. 
Figure 3 shows that financing with trade credit has a higher proportion in the Central Hungary Region compared to other territories of Hungary. Therewith, it would be interpretable due to the fact that greater competition trade credit plays a higher role as a marketing and price discrimination instrument.

\section{Exogenous Factors}

Most of the exogenous determinants (e.g. tax system, law) act the same way on all SMEs in the area of a concrete country, independent from its location. So, these effects on the capital structure cannot be different. Therefore, we deem relevant those exogenous factors in point of territorial differences which we could define not only at the national level but also at the regional level, and it shows significant differences.

\section{Characteristics of Input and Output Markets}

At the regional level, one of the most important factors is the characteristics of input and output markets. The competition is higher in central areas in input and also in output markets, which could be reflected in the sources as the higher proportion of account payables. Due to fewer performers in input market, SMEs cannot use longer prompts because they hang on their suppliers out and away. In central regions, most of the suppliers are more easily replaceable; therefore, there are better opportunities to use trade credit.

\section{Macroeconomic Characteristics}

Out of the macroeconomic characteristics, we can find territorial differences mostly in regional GDP. GDP per capita is an indicator which measures the relative wealth of territorial units. We suppose that areas with high GDP per capita dispose of more and better financing alternatives; therefore, GDP per capita is positively related to leverage for all types of firms. Bas, Muradoglu and Phylaktis (2009), using data from 25 developing countries, found significant positive relationship between GDP per capita and total debt and also in the case of short-term and long-term liabilities.

So, the most important factor of territorial differences is the region's economic performance, which we could measure with GDP per capita. The EU's development ranking grade regions is also based on this index, and in the early state of analysis it became unambiguous that our results strongly correlated with the EU's ranking. 


\section{Conclusions}

Based on our analysis, we can interpret the regional differences that we have found between the regions' economic indices and we could also investigate the capital structure of enterprises. In more developed regions, firms operate with higher leverage, while in less developed regions they use mainly equity.

With the help of cluster analysis, we identified six specific capital structure types in the case of enterprises with positive equity. Territorial differences were analysed by the frequency of the groups we appointed, and the more developed territorial units we have found, the less incidence of firms which finance themselves mainly with equity.

To explain the regional differences, we analysed the capital structure determining from the point of the relevant factors. The effect of company size and the characteristics of activities revealed themselves by an analysis across the clusters, but they did not furnish an answer to the territorial differences. Asset coverability could account for the differences in long-term liabilities, namely that the higher ratio of long-term debt is typical in more developed regions.

Analysing market position in combination with characteristics of input and output market, we found that, due to higher competition, trade credit plays a higher role in central areas than in other regions of the country. Thus, the differences of short- and long-term debts are already interpreted.

The higher proportion of equity or the lower leverage in the less developed regions is interpretable with the GDP per capita as an index of the relative wealth of territorial units. That is why we have found the EU's development ranking correlated with regional differences in capital structure.

\section{References}

Abonyi, J. (2006). Adatbányászat a hatékonyság eszköze, Budapest, Computer Books.

Balla, A.; Mateus, C. (2004). Empirikus vizsgálat a tőkestruktúra-döntésekről. Vezetéstudomány 35: 24-33.

Bas, T.; Muradoglu, G.; Phylaktis, K. (2009). Determinants of capital structure in developing countries, available at: http://citeseerx.ist.psu.edu/viewdoc/down load?doi=10.1.1.175.6261\&rep=rep1\&type=pdf.

Brealey, R. A.; Myers, S. C. (2005). Modern vállalati pénzügyek, Budapest, Panem. Eurostat (2011). Regional GDP per inhabitant in 2008 GDP per inhabitant ranged from $28 \%$ of the EU27 average in Severozapaden in Bulgaria to $343 \%$ in Inner London, available at: http://europa.eu/rapid/press-release_STAT-11-28_ en.htm?locale=en. 
Harris, M.; Raviv, A. (1991). The theory of capital structure. The Journal of Finance 46(1): 297-355.

Hungarian Act XXXIV of 2004 on Small and Medium-Sized Enterprises and the Promotion of Their Development (2004. évi XXXIV. törvény a kis- és középvállalkozásokról, fejlődésük támogatásáról).

Jensen, N. S.; Uhl, F. T. (2008). Capital structure in European SMEs. An analysis of firm- and country specific variables in determining leverage, Aarhus School of Business, University of Aarhus.

Kihanga, E. P. (2010). Trade credit in the Tanzanian rice market. Theses in Economics and Business, Groningen, The Netherlands: University of Groningen.

Kotulics, T. (2010). A KKV-k a statisztika rengetegében, presentation, Budapest: KKV Marketing Expo, 21 January 2010.

Központi Statisztikai Hivatal (KSH) (2011). A kis- és középvállalkozások helyzete. Gazdaság számokban 29, available at: http://www.gymskik.hu/download. php?id=4780.

Krénusz, Á. (2007). A vállalati tôkeszerkezet meghatározó tényezőinek új modellje és annak vizsgálata Magyarország példáján, Ph.D. dissertation, Budapest: Budapesti Corvinus Egyetem Gazdálkodástani Doktori Iskola.

Modigliani, F.; Miller, M. H. (1958). The cost of capital, corporation finance and the theory of investment. The American Economic Review 48(3): 261-297.

Nemzeti Fejlesztési és Gazdasági Minisztérium (NFGM) (2009). A kis- és középvállalkozások helyzete 2008 jelentés.

Psillaki, M.; Daskalakis N. (2009). Are the determinants of capital structure country or firm specific? Small Business Economics 33(3): 319-333.

Sogorb, F. (2002). How SME uniqueness affects capital structure: evidence from a 1994-1998 Spanish data panel. WP-EC, 2002-18, Instituto Valenciano de Investigaciones Económicas.

Song, H.-S. (2005). Capital structure determinants - An empirical study of Swedish companies. Electronic Working Paper Series 25: 1-25.

Warner, J. B. (1977). Bankruptcy costs: some evidence. Journal of Finance 32: $337-347$. 